\title{
The Noble Enigma: Chagas' Nominations for the Nobel Prize
}

\author{
Marilia Coutinho/ ${ }^{+}$, Olival Freire Jr.*, João Carlos Pinto Dias**
}

\author{
Center for Latin American Studies, University of Florida, 319 Grinter Hall, Gainesville, FL 32611, USA \\ *Instituto de Física, Universidade Federal da Bahia, Salvador, BA, Brasil **Centro de Pesquisas René \\ Rachou-Fiocruz, Belo Horizonte, MG, Brasil
}

Carlos Chagas, a Brazilian physician, discovered the American trypanosomiasis in 1909. Like other remarkable discoveries of those days, his work helped to articulate the insect-vector theory and other theoretical guidelines in tropical medicine. Unlike all other discoveries, all the stages of this work were accomplished in a few months and by a single man. Chagas' discovery was widely recognized at home and abroad. He was twice nominated for the Nobel Prize - in 1913 and in 1921-, but never received the award. Evidence suggests that the reasons for this failure are related to the violent opposition that Chagas faced in Brazil. The contentions towards Chagas were related to a rejection of the meritocratic procedures that gave him prominence, as well as to local petty politics.

Key words: Carlos Chagas - history of Brazilian medicine - history of Brazilian science - Chagas disease Pirajá da Silva

Ninety years ago, Carlos Chagas, a Brazilian physician, made a remarkable discovery (Chagas 1909a,b,c, 1910). In the period of a few months, Chagas was introduced to a blood sucking insect, identified trypanosomes in its midgut, carried out experiments on infection and invented a disease: the American trypanosomiasis, or Chagas disease. Thus stated, the sequence seems hardly real and the whole episode, unexpected. However, given the international scientific context of turn of the century tropical medicine (Harden 1985, Worboys 1976, 1993), it was not. Chagas' sequence from vector to disease is the most paradigmatic employment ever done of the insect-vector theory, tropical medicine's central guideline in those days (Coutinho \& Dias 1999). It was the tropical adventure dream of every parasite hunter, available only to the best and the luckiest. It is therefore easy to understand the enthusiasm with which Chagas' discovery was received by the international community (Chagas Filho 1974, 1993, Coutinho \& Dias 1999).

Recognition means different things for different disciplines in different times. It includes invitations for conferences, citations, collaborative re-

\footnotetext{
$\overline{{ }^{+} \text {Corresponding author. Fax: }}+1-352-392-7682$. E-mail: marilia@ufl.edu

Received 9 June 1999

Accepted 9 August 1999
}

search and awards. Chagas had his share of all that (Chagas Filho 1993). However, in the golden years of tropical medicine, when it was one of the most prestigious sciences, it could certainly mean the Nobel prize. Other parasite hunters, such as R Ross in 1902 and A Laveran in 1907, were Nobel laureates (the Nobel Foundation 1999). As the author of the most impeccable of those early discoveries, Chagas was obviously on the Nobel track. And, in fact, he was nominated for the prize, not only once, but twice officially and twice unofficially (Coutinho 1999). We are publishing here for the first time the fac similes of the two official Nobel nominations - one for the 1913 and the other for the 1921 Prize. None of them resulted in an award for Chagas. Now, THIS is unexpected and extraordinary.

To understand this puzzle, we must refer to the institutional setting and to the interplay of relevant characters in the reception of Chagas' discovery.

\section{THE CIRCLE OF PARASITE HUNTERS}

In this year of 1999, we are celebrating more than the 90 years of Chagas' discovery. We are celebrating the 100th birthday of tropical medicine. In 1899 two institutions and official support were granted to the circle of parasite hunters. In that year, P Manson, the founder of tropical medicine, defined tropical diseases as those caused by parasites that required an intermediary host in which part of the parasite's life cycle was to be completed. The "insect-vector" theory predicted that the vec- 
Chagas' Nomination for the Nobel Prize - Marilia Coutinho et al.

$$
\begin{gathered}
1920-1921 \\
15067
\end{gathered}
$$

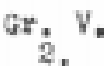

Irkon den 20 Jan, 1921.

Fio de Tenejro 1 e 21 fítcenbre

1020.

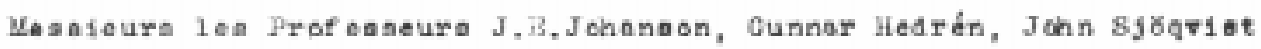

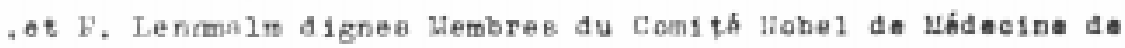

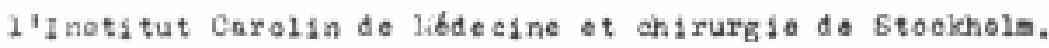

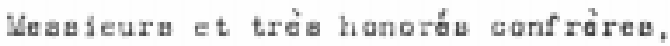

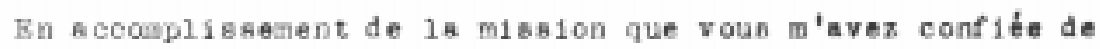

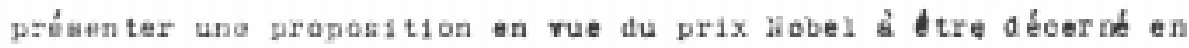

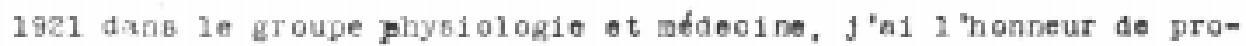

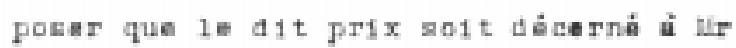

$$
\text { C }
$$

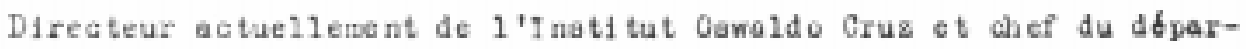
tement nouvellement ored, te la ande Fublique du Breali.

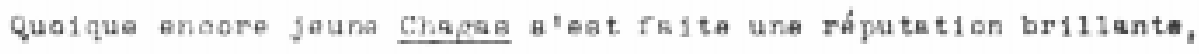

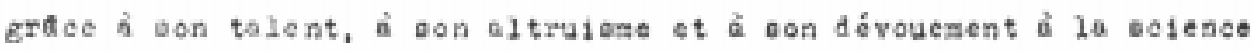

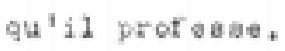

S'étant doné de hone heure aux átudeo ba ótriologiques bou

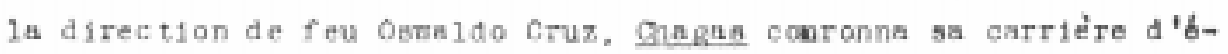

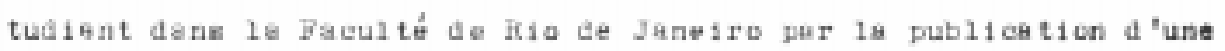

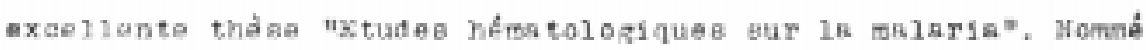

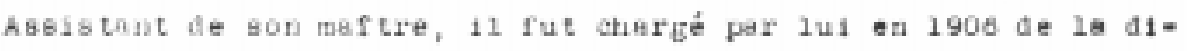

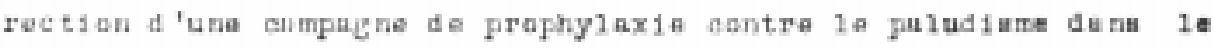

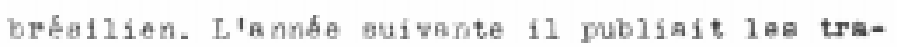

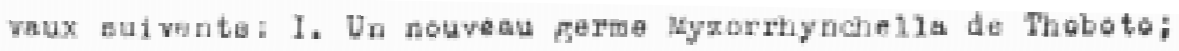

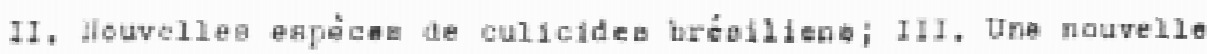
apéoe de germe Toeniorhynahua.

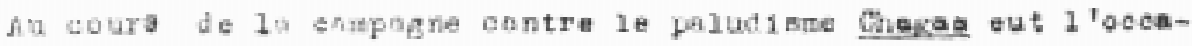

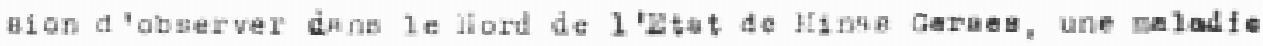

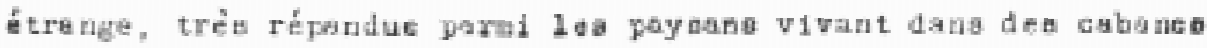

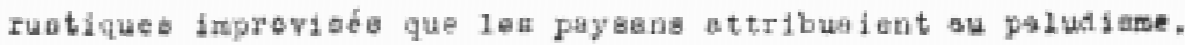




$$
2060-1652
$$

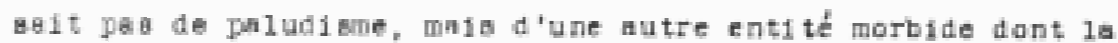

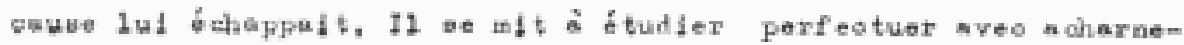

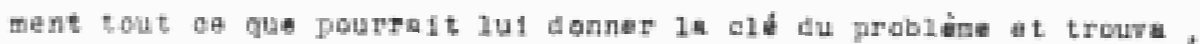

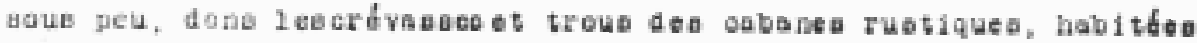

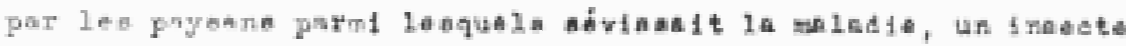

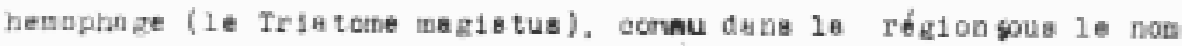

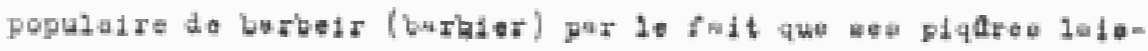

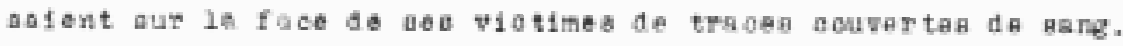

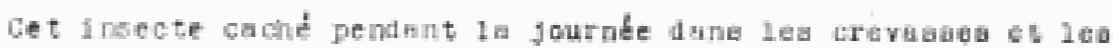

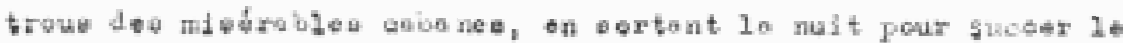
de

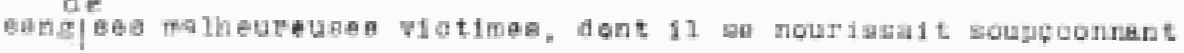

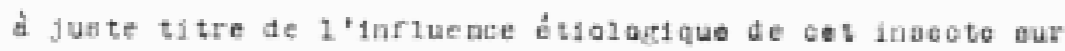

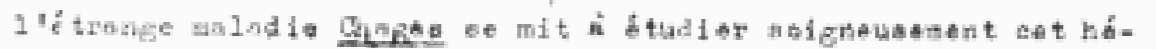

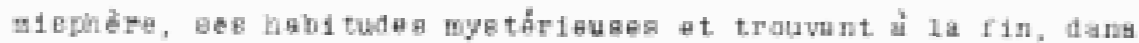

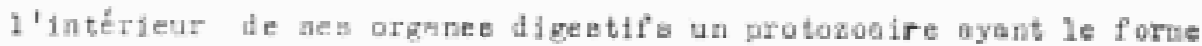

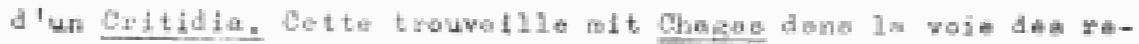

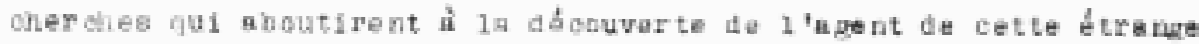

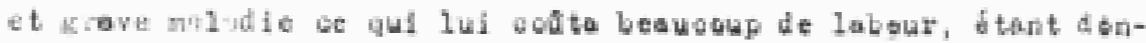

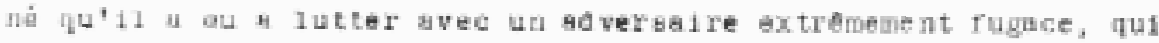

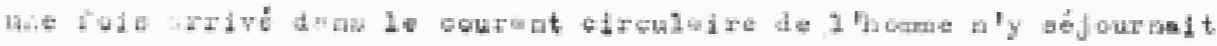

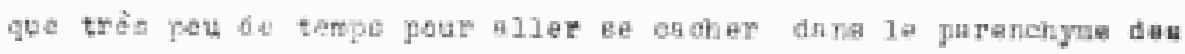

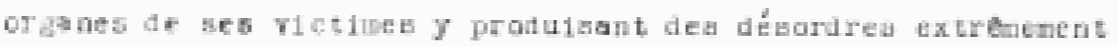

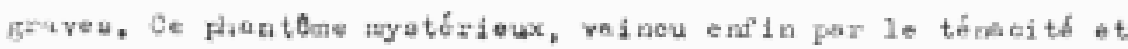

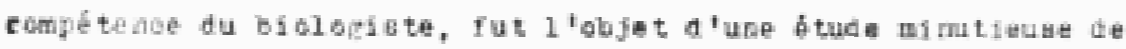

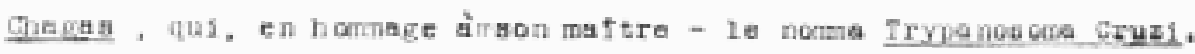

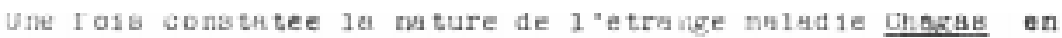

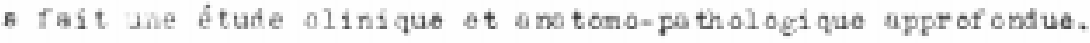

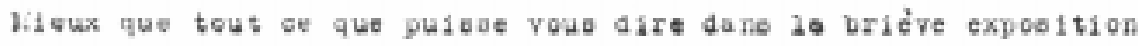

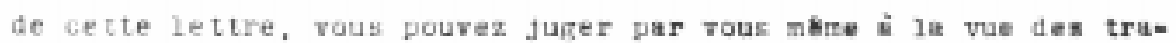

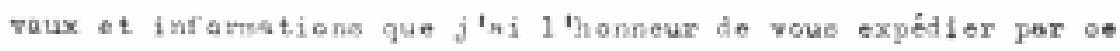
Gourier.

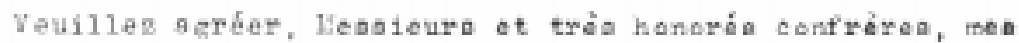

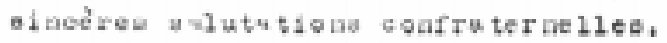

140 Prsia do Findura

H. de Gouvea 


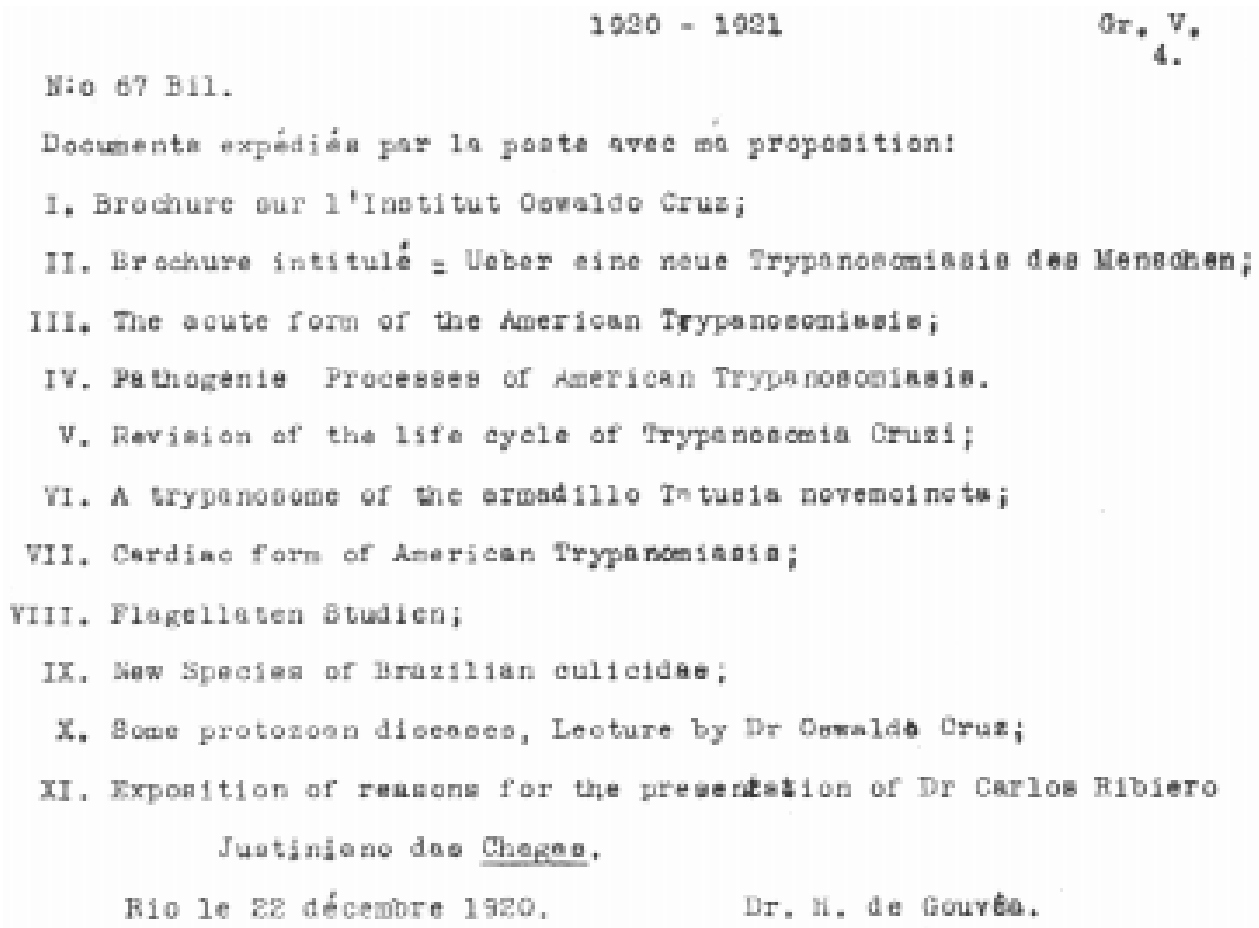

tor would be a blood sucking arthropod, most probably an insect (Harden 1985). This definition provided both the conceptual core for the early practitioners and a strong argument for tropical medicine's (institutional and educational) independence from bacteriology and "traditional" medicine (Worboys 1993). The new specialty dealt with tropical, as opposed to cosmopolitan diseases; they were caused by protozoa or more complex organisms, instead of bacteria or viruses; finally, they were transmitted by vectors, in contrast to the mechanical transmission of bacterial diseases. Such costly disciplinary independence was granted to a group of marginal army physicians partly because of the enormous importance that the sanitation of tropical possessions was assuming. In the last decades of the XIX century, the British Empire alone had grown into a vast tropical domain, chiefly in Africa. The health of white soldiers and settlers was permanently threatened by tropical diseases. Tropical medicine was, for these people, colonial and military business (Curtin 1989, Farley 1991, Worboys 1993).

With a list of impressive discoveries, institutions and resources for research, and the political support from colonial powers' governments, tropical medicine flourished as one of the most prestigious sciences of the early XX century (Worboys 1976, 1993). The discoveries included the eluci- dation of filariasis transmission by mosquitoes by P Manson in 1879; the identification of the malaria Plasmodium parasites, by A Laveran in 1880; the identification of the malaria insect vector and life cycle by R Ross and GB Grassi in 1897; the discovery of the causative agent of Kala azar, Leish mania donovani, by WB Leishman and C Donovan in 1900; the discovery of African trypanosomiasis by Bruce, between 1896 and 1902 and the identification of the life cycle of Schistosoma worms, that caused bilharzia, by R Leiper in 1915 (Farley 1991, Worboys 1983, Desowitz 1993).

\section{AN UNUSUAL DISCOVERY}

The close connections and present historical confusion between tropical medicine, colonial medicine and military medicine probably add to the oddity of Chagas' discovery: he was not European, Brazil was not a colony and Chagas' job had nothing to do with the military, much less with conquests and empires. Chagas' job concerned national development. Chagas worked for the Instituto Soroterápico de Manguinhos and, in 1907, he was sent to a small village in Minas Gerais to control a malaria epidemic. The outbreak had obstructed the construction of the Central do Brasil railroad (Chagas 1907).

In Lassance, Chagas was introduced, in 1908, to a blood sucking reduviid insect that preyed on 
the people at night. The general health condition was poor and strange symptoms called Chagas' attention. He dissected the insects and found critidia-like parasites in their gut. Assuming the protozoan could be an intermediary form of a vertebrate hemo-flagellate, Chagas sent some insects to Manguinhos for experimental infection. The parasites proved to be infective and to cause serious symptoms or kill the laboratory animals. In March 1909, Chagas found his first acute human case in Lassance (Chagas 1909c, 1922).

Chagas had just performed the perfect algorithm from vector to disease within a few months and alone. Compared to all the other tropical diseases, in which the discovery saga involved many years and many people, Chagas' discovery is again unusual. For example: the etiologic agent of bilharzia, the Schistosoma worms, were discovered between 1851 and 1852 by Theodor Bilharz. He identified the worms and its eggs. The life cycle and species were only correctly identified in 1915. The parasite that causes Kala azar was discovered in 1900 by Leishman and Donovan. Years after, it was identified as a protozoan of the genus Leishmania. The vector, Phlebotomus argentipes, was identified twenty six years later. Finally, the transmission mechanism became known only in 1940. The causative agent for malaria, a disease known from ancient times, was first observed in 1880 by Laveran. However, the transmission by the mosquito was only established in 1897 by Ross.

Word spread throughout the world about Chagas' remarkable discovery. He was immediately recognized. In 1910, Chagas was named full member of the Academia Brasileira de Medicina (National Academy of Medicine). Between 1911 and 1912 Chagas was invited to speak and to receive honors in Minas Gerais and São Paulo. In 1912, Chagas received the Schaudinn Prize, an international competition sponsored by the Institut für Schiffs- und Tropenkrankheiten of Hamburg. The prize was endowed to the most important contribution in protozoology every four years. Chagas won the award. The contenders were P Ehrlich, E Roux, E Metchnikoff, A Laveran, C Nicolle e WB Leishman (Chagas Filho 1993, Fonseca Filho 1974). Except for Leishman, they were all or became afterwards Nobel laureates: Laveran, in 1907; Ehrlich and Metchnikoff, in 1908; and Nicolle, in 1928 (the Nobel Foundation 1999).

\section{THE NOMINATIONS}

The Nobel Commission accepts nominations if they are made by specially appointed scientists. In 1911, the Commission assigned the task to Pirajá da Silva (Ringertz 1998).
Pirajá da Silva understood well the meaning of recognition. He had recently had some experience with credit attribution. In 1908, Pirajá da Silva wrote to Patrick Manson about the identification of Schistosoma eggs with lateral spines. The question was prompted by his repeated encounters with these eggs in the feces of his patients in Bahia, Brazil. At that time, an important controversy was going on about the number of species of Schistosoma worms, as well as the types of diseases they caused (Farley 1991). Bilharz had identified in Egypt the causative agent of bilharzia as Distomum haematobium, later re-named Schistosoma haematobium. Eggs retrieved from the urine of patients with the Egyptian disease carried a terminal spine. However, in 1902, Manson had identified eggs with lateral spines in the feces of a soldier who had been in the West Indies. Later, in 1907, L Sambon claimed that Manson's eggs represented a second species. He called it Schistosoma mansoni. Sambon had no strong evidence to support his claim: his propositions were based on insufficient amount of fixed material from the helminth collection at the London School of Tropical Medicine. Looss and Leiper, greater authorities than Manson and Sambon in schistosomiasis matters, explained away the laterally spined eggs as abnormal eggs produced by immature females. When Pirajá da Silva wrote to Manson about his findings, the argument about the Schistosoma species assumed a new status. Following some correspondence with Leiper, Pirajá provided, for the first time, ample evidence from autopsied human victims to differentiate the new Schistosoma from the haematobium. He published his findings in France and in England (Silva 1908/09, 1909). In 1912, Pirajá da Silva described, for the first time, a Schistosoma cercaria (Silva 1912), providing evidence for the complicated cycle of this flatworm. In spite of all the evidence, a good part of the international community, led by Leiper, ignored him and denied him credit for his work. $\mathrm{He}$ was never fully recognized as the true discoverer of Schistosoma mansoni and isn't even mentioned regarding the elucidation of the parasite's life cycle [In 1954, Pirajá da Silva was awarded the Bernhard Nocht medal, conferred by the Institut für Schiffsund Tropenkrankheiten. In the letter from Ernst Nauck, then director of the German institution, Pirajá da Silva is referred to as the scholar who settled a controversy over a previous discovery. In 1953, Philip Manson-Bahr published a review in which he acknowledged that Pirajá da Silva was the first researcher to describe the parasite that is now known as Schistosoma mansoni (MansonBahr 1953)]. 
Piraja da Silva's emphasis on Chagas' parasitological contribution in his nomination letter must be understood in the light of the latter's bitter experience.

Chagas did not receive the 1913 Nobel prize, which was awarded to CR Richet for his work on anaphylaxis (The Nobel Foundation 1999).

In 1920, the Nobel Commission assigned the task of nominating the candidate to H Gouvêa, a physician from Rio de Janeiro. This time, the longer letter insists on the medical significance of Chagas' findings. One of the reasons for this is that tropical medicine had lost much of its parasitological bias. After World War I, concerns over health in the tropics declined in the major European countries and the dominant approach in tropical medicine shifted from parasites and vectors to nutrition and environment (Worboys 1983).

Again, Chagas did not receive the prize. Having failed to confirm Chagas, the Commission did not award the prize to anyone in 1921 .

If Chagas' contribution was deemed important by everyone that counted, why were the nominations turned down? Some other source of opposition must have been at work.

\section{OPPOSITION AT HOME}

And in fact, opposition there was from the beginning. The unfolding of Chagas' discovery included not only honors and awards, but prominent positions and power. For each step Chagas took on the success ladder, the anti-Chagas group grew in number and resolve. As soon as 1910, Chagas was named head of Service in Manguinhos. The procedure that resulted in his nomination was strictly based on merit, according to a clear set of rules. Some were displeased - HB de Aragão, for one - both with the procedure and with Chagas' nomination. Hostility began to brew there (Chagas Filho 1993, Benchimol \& Teixeira 1993).

The surreptitious actions of the early antiChagas group came forth little by little. In 1916, at the Pan-American Medical Congress in Argentina, Chagas had a hard argument with R Kraus, from Argentina's Bacteriological Institute. Kraus claimed that he had found infected reduviid insects but no human victim of Chagas disease in Argentina (Fonseca Filho 1974, Chagas Filho 1974, 1993). The implications were serious and either meant that the parasite could be of little virulence, or the disease had only a local importance. In that occasion, Chagas was invited to visit Kraus' laboratory. There he found slides with Manguinhos stamps. He did not remember having ever received requests from Kraus (Chagas Filho 1993). It was clear that someone from Manguinhos had been feeding the German bacteriologist's contentions against Chagas.

With Oswaldo Cruz's death in 1917, Chagas became Manguinhos' director. Figueiredo de Vasconcellos, who had headed the Institute during Cruz's illness, became Chagas' enemy forever (Chagas Filho 1993).

Another important source of opposition was the prominent and controversial role Chagas played in Brazilian public health. The Department of Public Health was created in 1920 and Chagas was named director. Afrânio Peixoto, a powerful man in the Brazilian medical establishment, was upset (Chagas Filho 1993). He wanted the job and he did not share the meritocratic values underlying Chagas recognition abroad.

The challenges to Chagas' discovery climaxed in the "Academy debate" that happened between 1922 and 1924. HB Aragão, Afrânio Peixoto and Figueiredo de Vasconcelos were important players. In November 30, 1922, Afrânio Peixoto spoke to the Academia Nacional de Medicina at the reception of Figueiredo de Vasconcellos. He said:

"You could have found some mosquitoes, you could have invented a rare and unknown disease, about which much was said, but whose victims almost no one knew, hidden in a countryside dwelling of your province, a disease that you could magnanimously distribute among your fellow countrymen, accused of cretins" (Afrânio Peixoto, in Fonseca Filho 1974, p. 65).

Chagas demanded that a commission be formed to judge whether the disease was a new morbid entity, with well defined etio-pathogeny, characteristic symptoms and defined clinical syndromes and also judge his ethical procedure, the credits of his findings and its scientific and social relevance. The whole process took more than one year. In December 6, 1924, the commission decided in Chagas' favor (Fonseca Filho 1974, Chagas Filho 1993). However, it took another decade to re-establish the full recognition of Chagas' discovery: it was only after Chagas' death, in 1934, that research was again pursued and preventive measures were developed.

Whatever inquiries and oral debates there were following Chagas' nominations for the Nobel Prize faced an active anti-Chagas group at work in Manguinhos and at the Academia Nacional de Medicina. Stealthy and cautious in 1913, loud and aggressive in 1921. At this point, a second reason for Gouvêa's stress on the clinical aspects of Chagas' discovery is visible. In 1920, the disease itself was at stake and there were those that claimed that it was not a disease at all, or it was something of minor importance, restricted to a few areas.

Sierra Iglesias (1990) speculates that it was this local opposition that actually prevented 
Chagas from being awarded the Nobel prize in 1921 , the only nomination the author had knowledge of. We have found no documental evidence for that to this moment. However, the idea seems highly plausible.

Chagas' failure to be awarded the Nobel prize remains a mystery. However, this story sheds some light on previously neglected aspects of the adversities faced by scientists from scientifically nontraditional countries in getting recognition for their work. Even when they qualify as practitioners of the same scientific specialty, sharing concepts, issues and methods with their colleagues from scientifically traditional countries, they are somewhat outsiders. There are different sets of interests, institutions and political arrangements involved. But worst of all, they might be outsiders in their own countries, struggling to establish research in an environment that does not understand its role, and to function according to meritocratic rules that are utterly ignored. They are weak players abroad and they are weak players at home, where the elsewhere undisputed place of the scientist in society is still being carved.

\section{REFERENCES}

Benchimol JL, Teixeira LA 1993. Cobras, Lagartos e outros Bichos: uma História Comparada dos Institutos Oswaldo Cruz e Butantan. UFRJ, Rio de Janeiro.

Chagas C 1907. Adenda: Lassance, 1907, p. 391-413. In JR Cançado \& M Chuster (eds), Cardiopatia Chagásica, Fundação Carlos Chagas, Belo Horizonte.

Chagas C 1909a. Neue Trypanosomen. Archiv für Schiffs-und Tropenhygiene 13: 120.

Chagas C 1909b. Nova especie morbida do homem, produzida por um trypanozoma (Trypanozoma cruzi). Brazil Médico 16.

Chagas C 1909c. Nova tripanozomiase humana. Estudos sobre a morfologia e o ciclo evolutivo do Schizotrypanum cruzi, n. gen., n. $s$, ajente etiolojico de nova entidade morbida do homem. Mem Inst Oswaldo Cruz 1: 1-62.

Chagas C 1910. Nova entidade morbida do homem. Brazil Médico 43: 423-428; 44: 433-437; 45: 443-447.

Chagas C 1922. Descoberta do Trypanosoma cruzi e verificação da tripanozomiase americana. Retrospecto histórico. Mem Inst Oswaldo Cruz 15: 67-76 (número comemorativo da Independência do Brasil).
Chagas Filho C 1974. Histórico sobre a doença de Chagas, p. 5-21. In JR Cançado, Doença de Chagas, Imprensa Oficial, Belo Horizonte.

Chagas Filho C 1993. Meu Pai. Casa de Oswaldo Cruz/ Fiocruz, Rio de Janeiro.

Coutinho M 1999. O Nobel perdido. Folha de São Paulo, 7 de fevereiro, caderno 5, p. 11.

Chagas Filho C, Dias JCP 1999. A descoberta da doença de Chagas. Cadernos de Ciência e Tecnologia 16 in press.

Curtin D 1989. Death by Migration, Cambridge University Press.

Desowitz RS 1993. The Malaria Capers, WW Norton $\&$ Co., New York.

Farley J 1991. Bilharzia. A History of Imperial Tropical Medicine, Cambridge University Press.

Fonseca Filho, O 1974. A Escola de Manguinhos Contribuição para o Estudo do Desenvolvimento da Medicina Experimental no Brasil, EGRT, São Paulo.

Harden VA 1985. Rocky mountain spotted fever research and the development of the insect vector theory, 1900-1930. Bull History of Med 59: 449-466, 45051.

Manson-Bahr P 1953. PIRAJÁ DA SILVA, M.A. Estudos sôbre o "schistosomum mansoni" (19081916). Trop Dis Bull 50: 1152-53.

Nobel Foundation 1999. http://www.nobel.se

Ringertz N 1998 (Secretary, The Nobel Committee for Physiology or Medicine). Carta anexada às cópias dos fac-similes das nomeações feitas a Carlos Chgas, datada de 21 de dezembro de 1998.

Sierra-Iglesias JP 1990. Salvador Mazza - su Vida y su Obra-Redescubridor de la Enfermedad de Chagas, San Salvador de Jujuy, Universidad Nacional de Jujuy.

Silva MAP 1908/1909. La schistosomose à Bahia. Arch Parasitol 13: 283-302.

Silva MAP 1909. Contribution to the study of schistosomiasis in Bahia. J Trop Med Hyg 11: 159-164.

Silva MAP 1912. Cercaire brésilienne (Cercaria blanchardi) à queue bifurquée. Arch Parasitol 15: 398-400.

Worboys M 1976. The emergence of tropical medicine: a study in the establishment of a scientific specialty, p. 73-96. In G Lemaine et al. (eds), Perspectives in the Emergence of Scientific Disciplines, Mouton, Paris.

Worboys M 1983. The emergence and early development of parasitology, p. 1-18. In KS Warren \& JZ Bowers (eds), Parasitology - A Global Perspective, Springer-Verlag, New York.

Worboys M 1993. Tropical diseases, p. 512-536. In WF Bynum \& R Porter (eds), Companion Encyclopaedia of the History of Medicine, Routledge, London. 